\title{
STRENGTH BEHAVIOR OF MORTAR USING SLAG AS PARTIAL REPLACEMENT OF CEMENT
}

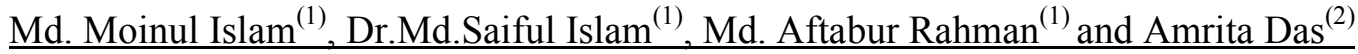

1. Department of Civil Engineering, Chittagong University of Engineering and Technology

E-mail: moinu191@yahoo.com

2. Graduate, Department of Civil Engineering, Chittagong University of Engineering and Technology

\begin{abstract}
This paper presents an experimental investigation carried out to study the effects of Ground Granulated Blast Furnace Slag (GGBFS) on strength development of mortar and the optimum use of slag in mortar. Cement was partially replaced with seven percentages $(10 \%, 20 \%, 30 \%, 40 \%, 50 \%, 60 \%$ and $70 \%)$ of slag by weight. Ordinary Portland cement (OPC) mortar was also prepared as reference mortar. A total of 400 cube and briquet mortar specimens were cast and compressive as well as tensile strength of the mortar specimens were determined at curing age of 3, 7, 14, 28, 60, 90 and 180 days. Test results show that strength increases with the increase of slag up to an optimum value, beyond which, strength values start decreasing with further addition of slag. Among the seven slag mortars, the optimum amount of cement replacement is about $40 \%$, which provides $19 \%$ higher compressive strength and $25 \%$ higher tensile strength as compared to OPC mortar.
\end{abstract}

KEY WorDS: Slag, Cement, Mortar, Compressive Strength, Tensile Strength, Hydration.

\subsection{INTRODUCTION}

Portland cement is and will remain a major construction material of choice in Civil Engineering construction. It is the most important constituent of concrete. Unfortunately, cement manufacturing consumes large amount of energy amounting about $7.36^{*} 10^{6} \mathrm{~kJ}$ per ton of cement (Tarun, 1996). Also, approximately 1 ton of $\mathrm{CO}_{2}$ is released into the atmosphere during the production of 1 tonne of cement (Min-Hong, 2001). Thus partial replacement of Portland cement in mortar / concrete by mineral by-products such as slag, fly ash, silica fume, etc, can significantly reduce $\mathrm{CO}_{2}$ emission (Ozkan, 2009).

Blended cements contain, in addition to Portland cement clinker and calcium sulfate, a latently hydraulic component such as granulated blast furnace slag or Class $\mathrm{C}$ fly ash, or a pozzolanic component such as natural pozzolan, Class F fly ash, condensed silica fume, calcined clay or a filler component such as limestone. The most common reason for blending ordinary Portland cement with these additions is economic. However, blended cements can be formulated to perform better than ordinary Portland cement and it offers a number of potential advantages to the manufactures: (a) increased plant capacity without the installation of a new kiln (b) reduced fuel consumption per ton of cement (c) reduced $\mathrm{CO}_{2}$ emissions per ton of cement (d) control of alkali-silica reactivity even with highalkali clinker (e) reduced production of cement kiln dust if the alkali content of the clinker is increased (f) improved durability due to the replacement of $\mathrm{Ca}(\mathrm{OH})_{2}$ with additional C-S-H.

Blast furnace slag is a by-product obtained during the manufacture of pig iron in the blast furnace and is formed by combination of earthy constituents of iron ore with limestone flux. When the molten slag is swiftly quenched with water in a pond or cooled with powerful water jets, it is formed into a fine, granular, almost fully non crystalline, glassy form known as granulated slag having latent hydraulic properties. Such granulated slag when finely ground and combined with Portland cement, has been found to exhibit excellent cementitious properties (Hwang, 1986). The reactivity of ground granulated blast furnace slag (GGBFS) is considered to be an important parameter to assess its effectiveness in concrete composites (Smolczyk, 1978).

Slag is used in concrete to achieve energy conservation, economic, ecological and technical benefits. It is used as pozzolanic mineral admixture in concrete and also has the hydraulic properties. According to ASTM C125, Pozzolan is a siliceous or siliceous and aluminous material which itself possesses little or no cementitious value but in finely divided form and in the presence of moisture, chemically reacts with calcium hydroxide at ordinary temperatures to form compounds possessing cementitious properties. According to ASTM C125, blast furnace slag is defined as the non-metallic product consisting essentially of silicates and aluminosilicates of calcium and other 
bases that is developed in a molted condition simultaneously with iron in a blast furnace.

ASTM C989, adopted in November 1982, provides for three strength grades of slags, depending on their respective mortar strengths when blended with an equal mass of Portland cement. The classifications are Grade-120, Grade-100 and Grade-80, based on the slag-activity index expressed as SP/P X100, where SP is the average compressive strength of slag cement mortar cubes and $\mathrm{P}$ is the average compressive strength of reference cement mortar cubes made without slag. Grades 100 and 120 are the most commonly used as admixtures in concrete. The chemical constituents of most of the blast furnace slags fall within the ranges shown in Table1.

\subsection{HydRation ChaRacteristics AND STRENGTH DeVELOPMENT OF SLAG MortaR}

When GGBF slag is mixed with water, initial hydration is much slower as compared with Portland cement. Therefore, Portland cement or alkali salts are used to increase the reaction rate. In the hydration process, GGBF slag produces calcium silicate hydrate cement paste. This valuable contribution from GGBF slag improves the paste-toaggregate bond in concrete. GGBF slag mixtures with Portland cement typically result in greater strength and reduced permeability. The principle constituents of blast furnace slag are silica, alumina, calcium and magnesia (reported as oxide), which comprise $95 \%$ of slags total makeup. Minor elements include manganese, iron and sulfur compounds as well as trace quantities of several others. Like Portland cement, most of the calcium oxide $(\mathrm{CaO})$ found in GGBFS is tied up as calcium silicate, calcium aluminates and calcium aluminosilicate. Although these compounds are not identical to those found in Portland cement (i.e., tricalcium silicate, tricalcium aluminate, etc.), they hydrate when activated by calcium hydroxide (lime) which is one of the by-product of Portland cement hydration.

Slag blended cement increases the compressive and flexural strength of conventional concrete and is often a vital component in producing high strength concrete. 28-days concrete strengths generally increase as the percentage of slag content increases up to about 50 percent of cementitious material. When Portland cement reacts with water, it forms calcium silicate hydrate $(\mathrm{CSH})$ and calcium hydroxide $\left(\mathrm{Ca}(\mathrm{OH})_{2}\right)$. $\mathrm{CSH}$ is the glue that provides strength and holds concrete together while $\mathrm{Ca}(\mathrm{OH})_{2}$ is a by product of Portland cement hydration that does not contribute to strength. When slag cement is used as part of the cementitious material in a concrete mix, it reacts with water and $\mathrm{Ca}(\mathrm{OH})_{2}$ to form more $\mathrm{CSH}$. The additional $\mathrm{CSH}$ densifies the concrete matrix thereby enhancing strength.

The reactivity of slag, to a great extent, depends on its composition. In general, the more basic the slag, the greater its hydraulic reactivity in the presence of alkaline activators; the higher the glassy phase, the lime, alumina and magnesia contents, the higher the hydraulic reactivity. In many specifications basicity is quantitatively defined as a mass ratio between the sum of $\left(\mathrm{CaO}+\mathrm{Al}_{2} \mathrm{O}_{3}+\mathrm{MgO}\right)$ and $\mathrm{SiO}_{2}$, which is known as the basicity factor. For instance, a basicity factor of $\geq 1$ is used in Germany to evaluate slags for use in blended cements. A high $\mathrm{MgO}$ content in some North American slags may sometimes be of concern for the formation of expansive particles. However, Stutterheim (1960) investigated concretes made from blended cements containing 50\% slag having up to $20 \% \mathrm{MgO}$ and found that these cements were as sound as comparable Portland cements, although he recommended that high $\mathrm{MgO}$ slags to be checked for soundness before use.

According to ACI Committee 226 (1994), the greater solid volume and higher fineness of slag allow more coarse aggregate to be used without a loss of workability. This often reduces the stickiness of the mix. Meusel and Rose (1983) investigated highly active slag at contents of $30 \%-50 \%$ in concrete and found that the slag improved the workability in all cases, but greater improvement was obtained with higher slag contents. High fineness of the slag component did not have a significant effect on the workability. Stutterheim (1968) observed that slag concretes had appreciably better workability than Portland cement concretes allowing for reductions in water content. According to Roy (1982), the effect of slag on workability is less pronounced than that of fly ash.

According to Gee (1979), early strength development in slag cement is affected by the chemistry of the clinker since the manner in which it releases calcium and alkali cations affects the rate of hydration of the slag. Clinker can be formulated with high lime content for use in blends with high slag contents. Hooton and Emery (1983) found that the compressive strength of slag cement mortars could be related to the chemical composition, fineness of grinding and degree of vitrification of the slag. Meusel and Rose (1983) observed that replacing $30 \%-50 \%$ of the cement with a highly 
active slag increased the concrete strength at 7 days and beyond. They recommend the optimizing of the slag content on the basis of mortar strengths.

When slag blended cement and water are mixed, a chemical reaction called hydration initiates, resulting in the creation of calcium-silicate-hydrate (CSH) and calcium hydroxide $(\mathrm{CH})$. $\mathrm{CSH}$ is a gel that is responsible for strength development in Portland cement pastes. Also, through pozzolanic activity, slag combines with free lime to produce the same cementitious compounds formed by the hydration of Portland cement. Hydration rate of slag is slower than that of Portland cement. So the blending of slag and Portland cement leads to retard the rate of strength development at early ages of curing.

\subsection{HEAT OF HYDRATION}

The hydration of cement is an exothermic reaction. High amount of heat is generally developed during this reaction. The generated heat causes the rise in temperature and accelerates the setting time and strength gain of mortar. In many structures, the rapid heat gain of cement increases the chances of thermal cracking leading to reduce concrete strength and durability. The applications of replacing cement by high percentage of slag can reduce the damaging effects of thermal cracking.

The hydration mechanism of slag is different from that of cement. When cement comes into contact with water, the dissolution of some phases takes place quite rapidly. But when slag is mixed with water, initial hydration is much slower than cement mixed with water. Hydration of slag in the presence of cement depends upon the breakdown and dissolution of the glassy slag structure by hydroxyl ions released during the hydration of cement and also the alkali content in cement. The hydration of slag consumes calcium hydroxide and uses it for additional CSH formation. According to Regourd (1980), Vanden Bosch (1980) and Roy and Idorn (1982), hydration of slag, in combination with cement, at normal stage, in general, is a two stage reaction. Initially and during the early hydration, the predominant reaction is with alkali hydroxide, but subsequent reaction is predominantly with calcium hydroxide. As a result the rate of heat liberation is correspondingly slow.

\subsection{RESEARCH SIGNIFICANCE}

Concrete is a commonly used construction material all over the world since last century. Concrete consumption in the year of 2000 was 12 billion tons
(Mehta, 2002). World population in the year 2000 was six billion. Based on this population, two tons of concrete is used per capita per year. Due to rapid development of infrastructures of developing countries, it is expected that in year of 2050, annual consumption of concrete would reach 18 billion tons per year. Typically concrete contains about $15 \%$ of cement by mass. Thus to produce such amount of concrete, 2.3 billion tons of cement will be necessary. Accordingly, a huge amount of $\mathrm{CO}_{2}$ will be added to green house gasses from such a huge amount of cement production. Although typical concrete contains less than $15 \%$ cement by mass, cement manufacturing accounts for about $80 \%$ of the total concrete industry's electricity use and approximately $66 \%$ of its fuel consumption. In order to reduce the emission of harmful green house gasses and fuel consumption, use of cement must be replaced with other environmentally friendly and efficient cementitious material (Mark Reiner, 2006). The local climate of Bangladesh is hot and humid with an average temperature of approximately $30^{\circ} \mathrm{C}$. This high ambient temperature is favorable for the early hydration of slag and also ensures the proper utilization of slag in an effective way which otherwise been dumped making environmental hazard. In the present study, slag mortar specimens were made with different cement replacement levels and cured up to 180 days. Compressive as well as tensile strength tests were carried out at different period to observe the performance of slag mortar.

\subsection{EXPERIMENTAL Program}

The experimental program was planned to predict the compressive strength and tensile strength of mortars using slag as replacement of cement. Cement replacement at various percentage levels were used in this investigation to observe the effects of different slag levels in mortar in contributing the compressive and tensile strength at various ages of curing.

\subsection{MATERIALS USED}

(a) Cement: ASTM Type I Portland Cement conforming to ASTM C-150 was used as binding material. The physical properties and chemical compositions of OPC are given in Table- 2 .

(b) Slag: Ground granulated blast furnace slag (GGBFS) was used for this investigation. The physical properties and chemical compositions of slag are given in Table-2. The slag activity indices at 7 and 28 days are 78.3 and $103.9 \%$, respectively. The slag meets the classification requirement of ASTM C989 for Grade 100. 
(c) Sand: Locally available natural sand passing through $4.75 \mathrm{~mm}$ sieve and retained on $0.015 \mathrm{~mm}$ sieve was used for this program. Gradation of the fine aggregates is given in Table- 3 .

\subsection{VARIABLES STUDIED}

(a) Mortar quality: Seven different mix proportions of cement:slag (90:10, 80:20, 70:30, $60: 40, \quad 50: 50, \quad 40: 60, \quad 30: 70)$ were used as cmentitious material. Cement slag mix ratio of 100:0 i.e. plain cement mortar specimens were also cast as reference mortar for comparing the properties of slag mortars.

(b) Exposure period: Specimens were tested periodically after the specified curing periods of 3 , $7,14,28,60,90$ and 180 days.

(c) Size of specimens: $50 \mathrm{~mm}$ x $50 \mathrm{~mm}$ x $50 \mathrm{~mm}$ cube specimens for compressive strength and briquette specimens of standard size for tensile strength tests were prepared as per ASTM standard.

(d) Mortar mix ratios: The mix ratio of cementitious material and sand was 1:2.75 for compressive strength and 1:3 for tensile strength test specimens. Details of mix proportion and materials are shown in Table-4.

(e) Curing environment and testing: A total of 400 mortar specimens were cast in the laboratory. After casting, the specimens were kept at $27^{\circ} \mathrm{C}$ temperature and $90 \%$ relative humidity for 24 hours. After demoulding, all the specimens were cured in water in a curing tank at room temperature. After specific exposure period, specimen was tested for compressive strength and tensile strength in accordance with test procedure ASTM C190-85 and C190-87.

\subsection{RESUlTS AND DisCUSSION}

\section{COMPRESSIVE STRENGTH}

The compressive strength of OPC and slag mortars as listed in Table-5, has been graphically presented in Fig.1. Also for the ease of comparison, the relative compressive strengths are plotted in Fig.2. Among all the mixes and for 3 days and 7 days compressive strength, no slag concrete achieved maximum strength. Test results showed that the 3 days compressive strength for OPC mortar is $12 \%$, $14 \%, 20 \%, 21 \%, 31 \%, 51 \%$ and $58 \%$ higher than slag mortar of replacement level 10\%, 20\%, 30\%, $40 \%, 50 \%, 60 \%$ and $70 \%$ respectively. Up to curing period of 14 days, compressive strength is seen to decrease with the increase in slag content when compared with no slag mortar.

Test results for 28 days compressive strength of the specimens up to $50 \%$ replacement level were very similar with OPC mortar strength. Compressive strength are slightly higher by $1 \%, 4 \%, 9 \%$ and $10 \%$ for slag mortar of cement slag ratio 80:20, 70:30, 60:40 and 50:50 respectively. 28 days strength for the $60 \%$ and $70 \%$ slag replaced mortar was lower by $14 \%$ and $25 \%$ respectively when compared with no slag mortar.

90 days compressive strength data obtained for $10 \%$, $20 \%, 30 \%, 40 \%$ and $50 \%$ slag replaced mortar were respectively $3 \%, 4 \%, 14 \%, 16 \%$ and $8 \%$ higher than no slag mortar and almost same for slag mortar of cement slag ratio of 90:10. $60 \%$ and $70 \%$ replacement level mortar strength were lower than no slag mortar by $7 \%$ and $15 \%$. After 180 days, maximum compressive strengths were obtained for $30 \%, 40 \%$ and $50 \%$ slag replaced mortar specimens with an increase in strength of $17 \%, 19 \%$ and $12 \%$ respectively as compared to OPC mortar. Also $10 \%$ and 50\% replacement level provided an increase in strength of $4 \%$ and $5 \%$ respectively when compared with no slag mortar.

In the presence of slag, $\mathrm{C}_{3} \mathrm{~S}$ hydration is slightly delayed, while hydration at later ages is accelerated (Ogawa, 1980). Slag also acts as a retarder to the hydration of $\mathrm{C}_{3} \mathrm{~A}$ (Uchikawa and Uchida, 1980). The setting time of slag-blended cement is delayed as compared to ordinary Portland cement by 10 to 20 minutes per $10 \%$ addition of slag (Hogan and Meisel, 1981). It has also been reported that the chemical composition of the calcium silicate hydrate formed in hardened blended cement paste was different form that of Portland cement hydration products. Uchikawa (1986) also reported a higher alkali retaining capacity of the hydration product of the slag blended material. For this reason, mortar made with slag will have lower strength than cement mortar at early ages and substantially higher strength at longer ages of curing.

\section{TENSILE STRENGTH}

The tensile strength of mortar mixes made with and without slag was determined at the ages of 3, 7, 14, 28, 60, 90 and 180 days. Fig.3 shows the development of tensile strength with age for different slag mortars. These values are also presented in Table-6. Also for the ease of comparison, the relative tensile strength is plotted in Fig.4. The tensile strength of the specimens is seen to increase with age. At early ages of curing (3 days and 7 days), the tensile strength decreases with 
increase in slag content in mortar. However, the rate of decrease diminished with the increasing age of curing. The slag mortar specimens shows that tensile strength results are almost identical with that of reference mortar up to cement replacement of $50 \%$ at 28 days. Tensile strength values are $101 \%, 102 \%$, $107 \%, 109 \%$ and $106 \%$ for slag mortar of replacement level of $10 \%, 20 \%, 30 \%, 40 \%$ and $50 \%$ for the curing age of 28 days. $60 \%$ and $70 \%$ replaced slag mortar achieved $85 \%$ and $70 \%$ strength of OPC mortar.

After 90 days, a maximum tensile strength of 6.1 $\mathrm{MPa}$ was achieved for the slag mortar of $40 \%$ replacement level with an increase of $18 \%$ higher than the no slag mortar. Even $30 \%$, and $50 \%$ slag mortar showed higher tensile strength of $13 \%$ and $12 \%$ respectively than OPC mortar. After 180 days, a maximum tensile strength of $7.4 \mathrm{MPa}$ was also achieved for $40 \%$ replacement mortar, which is $25 \%$ higher than the reference mortar. Even $30 \%$ and $50 \%$ slag replaced mortar showed $19 \%$ and $18 \%$ higher strength. However, $60 \%$ and $70 \%$ slag mortar provides a decrease in strength of about $8 \%$ and $15 \%$ respectively. According to Mehta (1986), pozzolan cements are generally somewhat slower to develop strength than slag cements. Given long-term continuous curing, the ultimate strengths of slag cement mortar will be higher than that of Portland cement. According to Gee (1979), early strength development in slag cement is affected by the chemistry of the clinker, since the manner in which it releases calcium and alkali cations affects the rate of hydration of the slag. As slag cement takes time to produce $\mathrm{Ca}(\mathrm{OH})_{2}$ by hydration of cement, strength gaining rate slows down at initial ages of curing but increases for later age of curing.

\subsection{CONCLUSION}

Based on the results of the investigation conducted on different slag mortars made with various level of cement replacement and cured for various curing period up to 180 days, the following conclusions can be drawn:

(1) Slag mortar mix having various cement replacement level up to $50 \%$ exhibited satisfactory results for both compressive and tensile strength.

(2) The optimum use of slag in the mortar is observed to be $40 \%$ of cement. Slag mortars with $40 \%$ cement replacement shows 19\% higher compressive strength than OPC mortar after 180 days curing. The corresponding increase in tensile strength is reported to be $25 \%$.

(3) Use of high volume slag as a replacement of cement, in any construction work, provides lower impact on environment (reduced $\mathrm{CO} 2$ emission) and judicious use of resources (energy conservation, use of by-product etc.)

(4) Use of slag reduces the amount of cement content as well as heat of hydration in a mortar mix. Thus, the construction work with slag concrete becomes economical and also environmentally safe.

(5) Slower Rate of hydration in case of slag cement concrete/mortar lower the risk of thermal cracking.

\begin{tabular}{|c|c|}
\hline $\begin{array}{c}\text { Chemical constituents } \\
\text { (as oxides) }\end{array}$ & $\begin{array}{c}\text { Composition } \\
\text { (\% by mass) }\end{array}$ \\
\hline $\mathbf{S i O}_{\mathbf{2}}$ & $32-40$ \\
\hline $\mathbf{A l}_{\mathbf{2}} \mathbf{O}_{\mathbf{3}}$ & $7-17$ \\
\hline $\mathbf{C a O}$ & $29-42$ \\
\hline $\mathbf{M g O}$ & $8-19$ \\
\hline $\mathbf{S}$ & $0.7-2.2$ \\
\hline $\mathbf{F e}_{\mathbf{2}} \mathbf{O}_{3}$ & $0.1-1.5$ \\
\hline $\mathbf{M n O}$ & $0.2-1.0$ \\
\hline
\end{tabular}

Table 1: Chemical Composition of Blast Furnace Slags Produced in the United States and Canada (ACI 226, 1987) 


\begin{tabular}{|c|c|c|}
\hline Physical properties & $\begin{array}{l}\text { ASTM Type-I } \\
\text { Cement }\end{array}$ & Slag \\
\hline \multicolumn{3}{|l|}{ Fineness } \\
\hline Passing \#200 Sieve, \% & $95 \%$ & $99 \%$ \\
\hline Blains, $\mathrm{cm}^{2} / \mathrm{gm}$ & 3400 & 4100 \\
\hline \multicolumn{3}{|l|}{ Compressive Strength, MPa } \\
\hline 3 days & 17.3 & -- \\
\hline 7 days & 24.3 & -- \\
\hline 28 days & 33.0 & -- \\
\hline Specific gravity & 3.13 & 2.99 \\
\hline \multicolumn{3}{|l|}{ Chemical analysis, \% } \\
\hline Calcium Oxide, $\mathrm{CaO}$ & 64.50 & 41.3 \\
\hline Silicon Dioxide, $\mathrm{SiO}_{2}$ & 20.58 & 32.7 \\
\hline Aluminum Oxide, $\mathrm{Al}_{2} \mathrm{O}_{3}$ & 6.42 & 18.4 \\
\hline Ferric Oxide, $\mathrm{Fe}_{2} \mathrm{O}_{3}$ & 4.53 & 1.3 \\
\hline Magnesium Oxide, $\mathrm{MgO}$ & 1.12 & 4.2 \\
\hline Sulfur Trioxide, $\mathrm{SO}_{3}$ & 1.45 & -- \\
\hline Sulfer, S & -- & 1.8 \\
\hline Loss on Ignition & 0.9 & -- \\
\hline Insoluble Residue & 0.5 & -- \\
\hline
\end{tabular}

Table 2 : Physical Properties and Chemical Composition of Ordinary Portland Cement and Slag

\begin{tabular}{|c|c|c|}
\hline & $\begin{array}{c}\text { Cumulative } \\
\text { \% Passing (for Compressive Strength) }\end{array}$ & $\begin{array}{c}\text { Cumulative } \\
\text { Passing (for Tensile Strength) }\end{array}$ \\
\hline ১.১৮ সস (ঘড়. ১৬) & ১০ & ১০০ \\
\hline ৮৫০ ক্রস (ঘড়. ২০) & -- & ৮- \\
\hline ৬০০ ক্রস (ঘড়. ৩০) & ৯৫ & -- \\
\hline ৪২৫ ক্রস (ঘড়. ৪০) & ৭৫ & -- \\
\hline ৩০০ ক্রস (ঘড়. ৫০) & ২৯ & -- \\
\hline ১৫০ ক্রস (ঘড়. ১০০) & ২ & \\
\hline
\end{tabular}

Table 3: Grading of Fine Aggregate 


\begin{tabular}{|c|c|c|c|c|}
\hline $\begin{array}{l}\text { Sl. } \\
\text { No }\end{array}$ & Specimen Type/ Materials & $\begin{array}{l}\text { For Compressive } \\
\text { strength test }\end{array}$ & $\begin{array}{l}\text { For Tensile } \\
\text { strength test }\end{array}$ & Remarks \\
\hline 1. & Specimen & $50 \mathrm{~mm} \mathrm{Cube}^{*}$ & $25 \mathrm{~mm}$ Briquette ${ }^{* *}$ & \multirow{4}{*}{$\begin{array}{l}\text { Materials } \\
\text { required for } 6 \\
\text { specimens }\end{array}$} \\
\hline 2. & $\begin{array}{c}\text { Cementitious materials } \\
(\text { Cement }+ \text { Slag })\end{array}$ & $500 \mathrm{gm}$ & 300 & \\
\hline 3. & Sand & $1375 \mathrm{gm}$ & 900 & \\
\hline 4. & Water & $242 \mathrm{ml}$ & $132 \mathrm{ml}^{* * *}$ & \\
\hline
\end{tabular}

${ }^{*}$ ASTM C190-85 $\quad{ }^{* *}$ ASTM C190-87 $\quad{ }^{* * *}$ Normal Consistency $=27 \%$

Table 4: Mix Proportions of Various Ingredients of Cement: Slag Mortar

\begin{tabular}{|c|c|c|c|c|c|c|c|c|}
\hline Replacement Level & \multicolumn{9}{|c|}{ Ce:Sg } \\
\hline Curing Period (days) & $\mathbf{1 0 0 : 0}$ & $\mathbf{9 0 : 1 0}$ & $\mathbf{8 0 : 2 0}$ & $\mathbf{7 0 : 3 0}$ & $\mathbf{6 0 : 4 0}$ & $\mathbf{5 0 : 5 0}$ & $\mathbf{4 0 : 6 0}$ & $\mathbf{3 0 : 7 0}$ \\
\hline 3 & 17.3 & 15.3 & 14.8 & 13.9 & 13.7 & 11.9 & 8.4 & 7.3 \\
\hline 7 & 24.3 & 22.8 & 21.9 & 21.1 & 20.6 & 17.3 & 13.5 & 12.3 \\
\hline 14 & 27.6 & 26.8 & 25.9 & 25.4 & 24.9 & 22.9 & 20.5 & 19.6 \\
\hline 28 & 33.0 & 32.5 & 33.4 & 34.4 & 36.0 & 33.1 & 28.2 & 24.8 \\
\hline 60 & 40.9 & 41.5 & 42.3 & 44.9 & 46.5 & 43.6 & 37.4 & 34.1 \\
\hline 90 & 43.3 & 44.4 & 45.2 & 49.4 & 50.2 & 46.9 & 40.4 & 36.7 \\
\hline 180 & 47.5 & 49.5 & 50.0 & 55.6 & 56.4 & 53.3 & 45.8 & 41.1 \\
\hline
\end{tabular}

\section{Ce : Cement Sg : Slag}

Table 5 : Compressive Strength (MPa) of Cement : Slag Mortars for Various Replacement Level of Cement

\begin{tabular}{|c|c|c|c|c|c|c|c|c|}
\hline Replacement Level & \multicolumn{9}{|c|}{ Ce:Sg } \\
\hline Curing Period (days) & $\mathbf{1 0 0 : 0}$ & $\mathbf{9 0 : 1 0}$ & $\mathbf{8 0 : 2 0}$ & $\mathbf{7 0 : 3 0}$ & $\mathbf{6 0 : 4 0}$ & $\mathbf{5 0 : 5 0}$ & $\mathbf{4 0 : 6 0}$ & $\mathbf{3 0 : 7 0}$ \\
\hline 3 & 3.0 & 2.8 & 2.7 & 2.4 & 2.4 & 2.1 & 1.4 & 1.3 \\
\hline 7 & 3.6 & 3.3 & 3.3 & 3.2 & 3.1 & 2.5 & 2.0 & 1.8 \\
\hline 14 & 3.8 & 3.7 & 3.6 & 3.5 & 3.5 & 3.3 & 2.8 & 2.7 \\
\hline 28 & 4.2 & 4.3 & 4.3 & 4.5 & 4.6 & 4.5 & 3.6 & 3.2 \\
\hline 60 & 4.9 & 4.9 & 5.1 & 5.3 & 5.5 & 5.3 & 4.4 & 3.9 \\
\hline 90 & 5.2 & 5.3 & 5.4 & 5.8 & 6.1 & 5.8 & 4.7 & 4.3 \\
\hline 180 & 5.9 & 6.1 & 6.3 & 7.0 & 7.4 & 7.0 & 5.4 & 5.0 \\
\hline
\end{tabular}

Ce : Cement Sg : Slag

Table 6 : Tensile Strength (MPa) of Cement : Slag Mortars for Various Replacement Level of Cement 


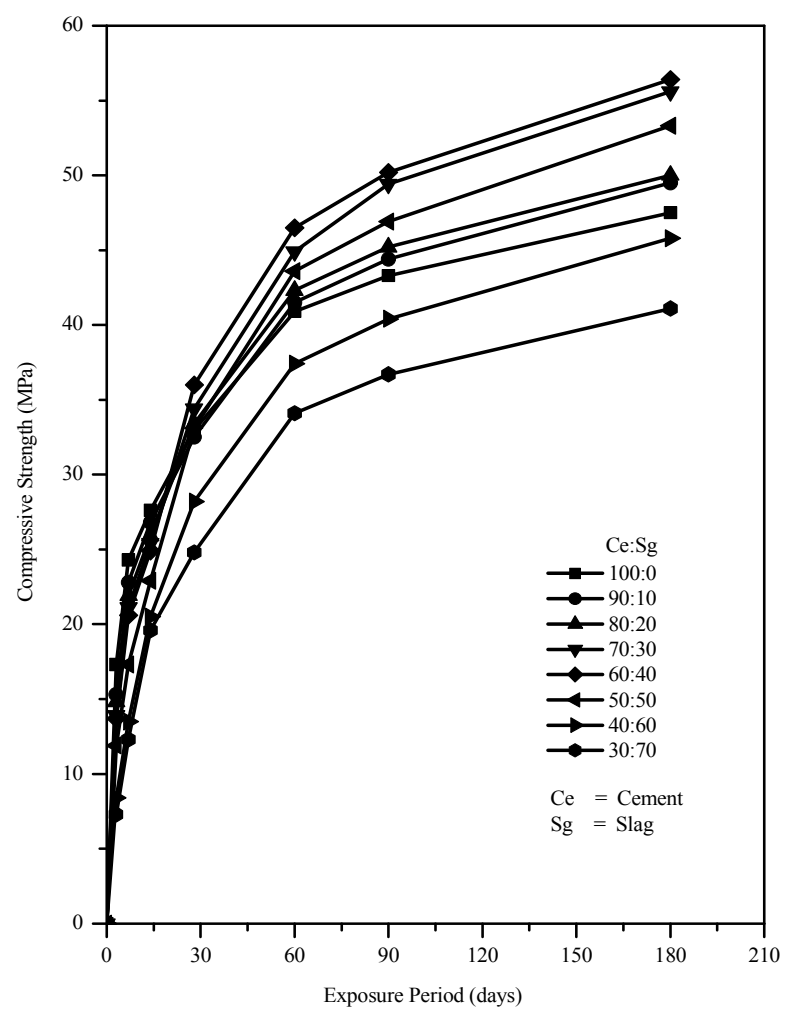

Fig.1: Compressive strength- exposure time relation for slag mortars

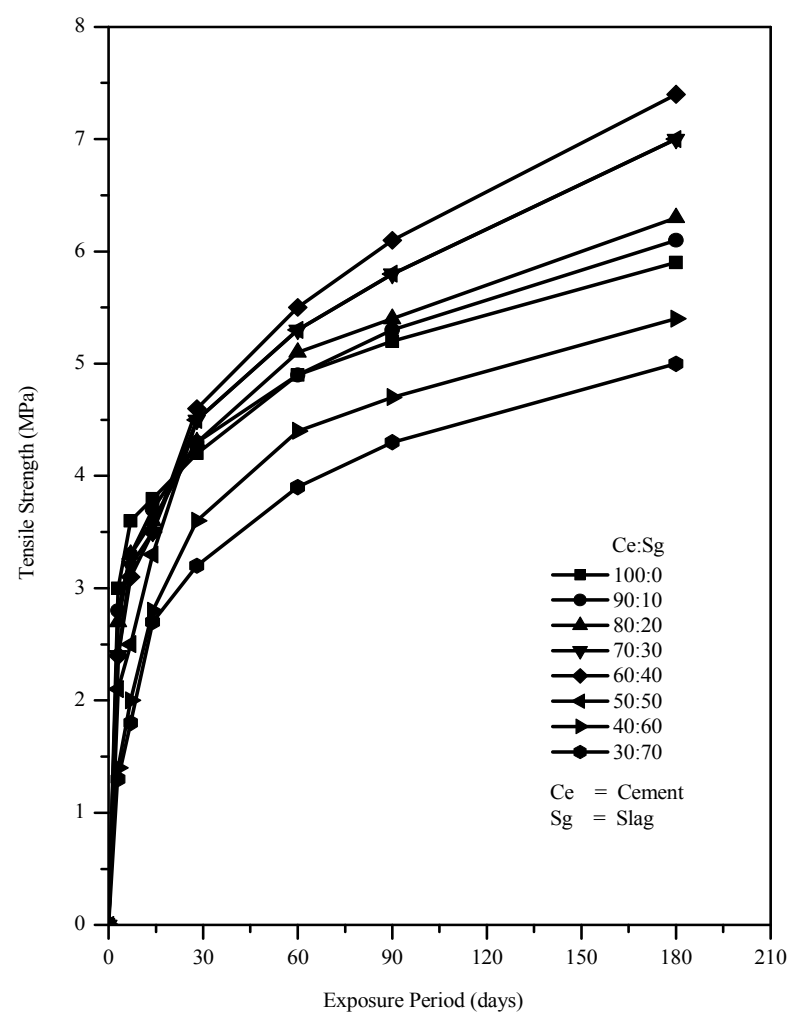

Fig.3: Tensile strength- exposure time relation for slag mortars

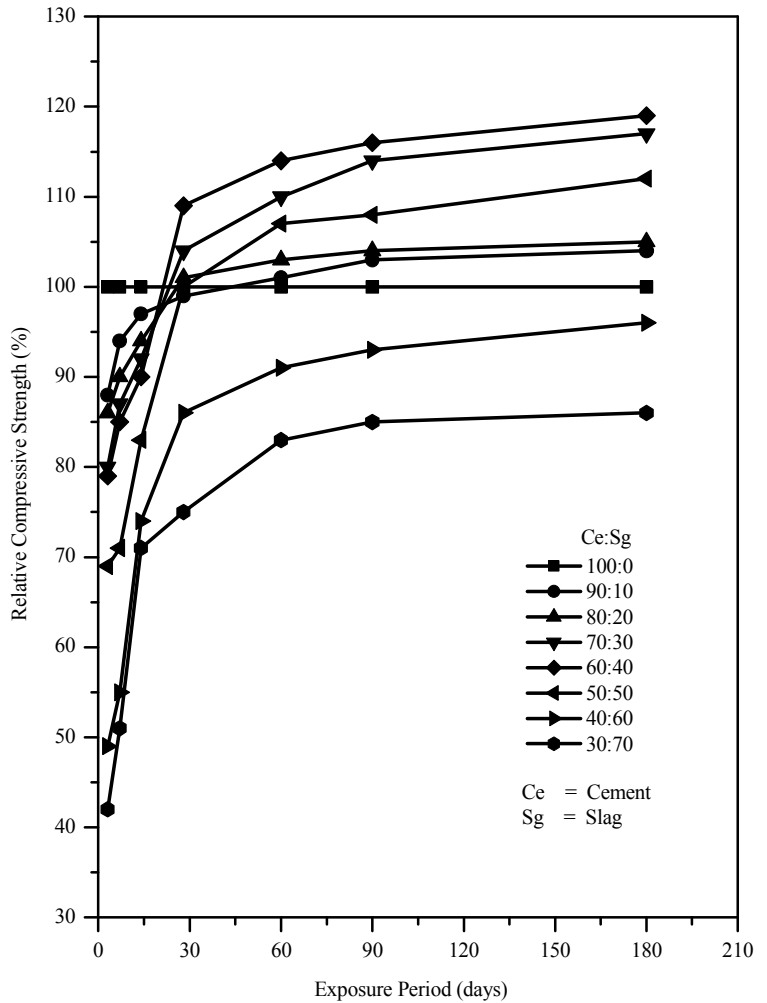

Fig.2: Relative compressive strength-exposure time relation for slag mortars

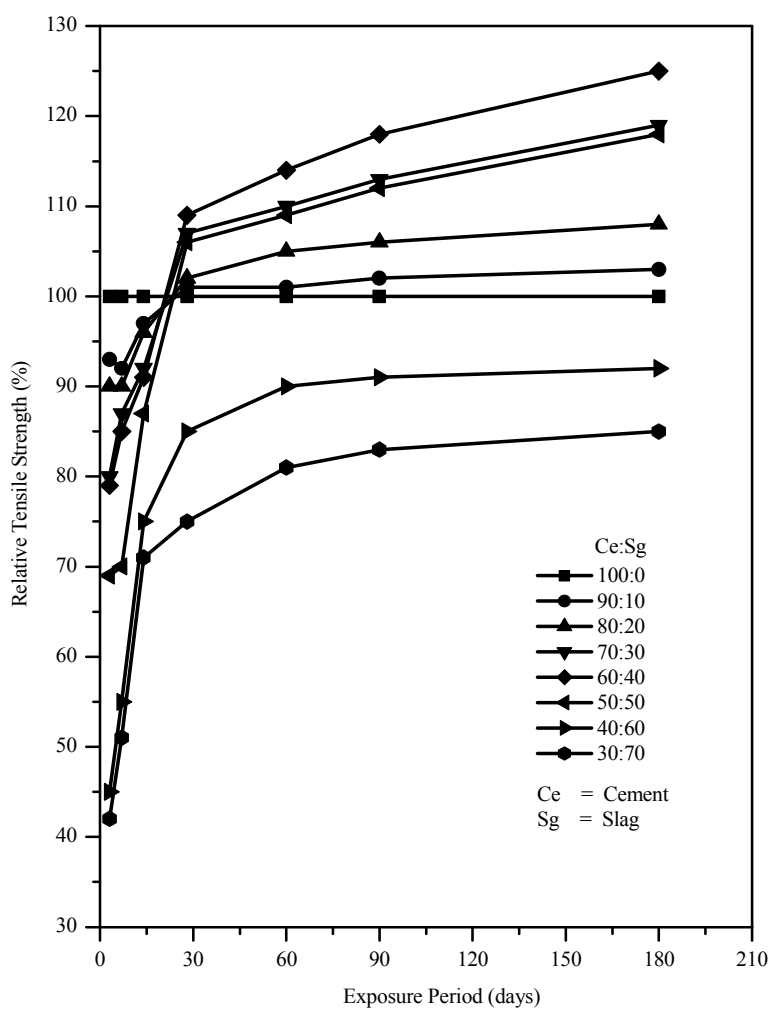

Fig.4: Relative tensile strength-exposure time relation for slag mortars 


\section{REFERENCES}

[1] Gee, Kenneth H.(1979) "The potential for slag in blended cements," Proceedings, $14^{\text {th }}$ International Cement Seminar, Rock Products, pp. 55-53.

[2] Hwang, C.L., Lin, C.Y.,(1986) "Strengrh development of blended furnace slag cement mortars," SP 91-65, Proceedings of the $2^{\text {nd }}$ International Conference on Fly Ash, Silica Fume, Slag and Natural Pozzolans in concrete, Vol. 2, American Concrete Institute, USA, pp. 1323-1340.

[3] Hogan, F. J. and Meusel, J. W.(1981) "Evaluation for durability and strength development of a ground granulated blast furnace slag", Cment, Concrete and Aggregates, CCAGDP, Vol. 3, No. 1, pp. 40-52.

[4] Hooton, R. D. and Emery, J.J.(1983) "Glass Content Determination and Strength Development Predictions for Vitrified Blast furnace Slag," Fly Ash, Silica Fume, Slag \& Other Mineral by-roducts in Concrete, ACI SP-79, pp.943-962.

[5] Mark, Reiner., and Kevn, Rens.(2006), HighVolume Slag Concrete: Analysis and Application, Practice Periodical on Structural Design and Construction, Vol.11, No.1, pp.58-64.

[6] Mehta P. K.(1986) "Effect of fly ash composition on sulfate resistance of concrete," Journal of the American Concrete Institute, Vol. 83, No.6, pp.994-1000.

[7] Mehta, P. K.,(2002) Greening of the Concrete Industry for Sustainable Development, ACI Concrete International, Vol.24, No.7, pp. 23-28.

[8] Min-Hong, Zhang., Marcia, C. Blanchette., and V, M. Malhotra.,(2001), Leachability of Trace Metal Elements from Slag Concrete: Results form ColumnLeaching and Batch Leaching Tests, ACI Materials Journal, Vol.98, No.2, pp.126-136.

[9] Meusel, J. W. and Rose, J. H.(1983) "Production of Granulated Blast Furnace Slag at Sparrows Point, and the Workability and Strength Potential of Concrete Incorporation the Slag," Fly Ash, Silica Fume, Slag \& Other Mineral By- Products in Concrete, ACI Sp-79, pp.867-890.

[10] Ogawa, K.; Uchikawa, H.; Takenoto, K., and Yasui, I,(1980) "The mechanism of the hydration in the system CS Pozzolana," Cement and Concrete Research, Vol.10, No.5, pp. 683-696.

[11] Ozkan, Sengul., and Mehmet, Ali. Tasdemir., (2009), Compressive Strength and Rapid Chloride Permeability of Concretes with Ground Slag and Slag,
Journal of Materials in Civil Engineering, Vol.21, No.9, pp.494-501.

[12] Regourd, M., (1980)“Characterization of thermal activation of slag cements," Proceedings of the $7^{\text {th }}$ International Congress on the chemistry of cements (Paris) 2 (III-3), pp.105-111.

[13] Roy, D. M. and Idorn, G.M.(1982) "Hydration, Structure and Properties of Blast Furnace Slag Cements, Mortars and Concrete," ACI Journal, Vol. 79, No. 6, pp.444-457.

[14] Tarun, R. Naik., Shiw, S. Singh., and Mohammad, M. Hossain., (1996), Permeability of High Strength Concrete Containing Low Cement Factor, Journal of Energy Engineering, Vol.122, No.1, pp.2139.

[15] Smolczyk, H.G., (1978)“The effect of chemistry of slag on the strength of blast furnace cements", ZemKalk-Gips 31 (6), pp.294-296.

[16] Stutterheim, N.,(1960) "Properties and Uses of High Magnesia Portland Slag Cement Concretes," Journal of the American Concrete Institute, Proceedings V:56, Vol.31, No.10, pp.1027-1045.

[17] Stutterheim, Niko.(1968) "Portland Blast furnace Cements- A Case for Separate Grinding of Slag,"Supplementary Paper IV-113, fifth International Symposium of the Chemistry of Cement, Tokyo, pp.270-276.

[18] Uchikawa,v H.(1986)"Effect of blending components on hydration and structure formation," $8^{\text {th }}$ International Congress on the Chemistry of Cement, Rio de Janeiro, I, 249-280.

[19] Uchikawa, H. and Uchida, S.(1980) "Influence of pozzolans on the hydration of $\mathrm{C} 3 \mathrm{~A}$, , $7^{\text {th }}$ international Congress on the Chemistry of Cement, Paris, III, pp.IV23-IV-29.

[20] Vanden Bosch, V.D., (1980) "Performance of mortar specimens in chemical and accelerated marine exposure, performance of concrete in Marine Environment," ACI SP-65, American Concrete Institute, pp. 487-507.

[21] Roy, D.M., and Idorn, G. M.,(1982) "Hydration, structure and properties if blast furnace slag cements, mortars and concrete, Proc.-Am, Concrete International 79 (6), pp. 445-457. 